\author{
Paweł Stelmach \\ Akademia Wychowania Fizycznego w Krakowie \\ Wydział Turystyki i Rekreacji \\ Katedra Polityki Turystycznej \\ Zakład Ekonomii i Zarządzania \\ pawel.stelmach@awf.krakow.pl
}

\title{
STRUKTURA DYSTRYBUCJI USŁUG UZDROWISKOWYCH A FUNKCJA UZDROWISKOWA GMIN UZDROWISKOWYCH WOJEWÓDZTW KUJAWSKO-POMORSKIEGO, POMORSKIEGO I PODKARPACKIEGO
}

\begin{abstract}
Abstrakt: Celem autora artykułu jest określenie i wyjaśnienie związku między strukturą dystrybucji usług uzdrowiskowych a funkcją uzdrowiskową gmin województw kujawsko-pomorskiego, pomorskiego i podkarpackiego. Wykorzystano technikę analizy korelacji rang Spearmana oraz analizę prostej regresji liniowej. Dane statystyczne pochodziły z Banku Danych Lokalnych oraz niepublikowanych zbiorów danych GUS. W celu wyjaśnienia zidentyfikowanych związków analizowano szeregi czasowe wskaźników struktury dystrybucji usług uzdrowiskowych i funkcji uzdrowiskowej. W przypadku pięciu z dziewięciu analizowanych gmin (Horyniec-Zdrój, Solina, Ustka, Ciechocinek i Inowrocław) występuje związek funkcyjny między funkcją uzdrowiskową gmin a udziałem kuracjuszy komercyjnych w strukturze dystrybucji usług uzdrowiskowych.
\end{abstract}

Słowa kluczowe: funkcja uzdrowiskowa, funkcja turystyczna, uzdrowiska, dystrybucja, kuracjusze pełnopłatni.

\section{WPROWADZENIE}

Podjętym problemem badawczym jest weryfikacja związku struktury dystrybucji usług uzdrowiskowych $\mathrm{z}$ funkcją uzdrowiskową gmin w województwach kujawsko-pomorskim, pomorskim i podkarpackim. Celem pracy jest określenie i wyjaśnienie tej relacji. Postawiono zatem następujące pytanie badawcze: czy, a jeżeli tak, to w jakim stopniu, występuje związek lub zależność między strukturą dystrybucji usług uzdrowiskowych, a funkcją uzdrowiskową $\mathrm{w}$ analizowanych gminach?

$\mathrm{W}$ niniejszej pracy poszerzono zakres analiz $\mathrm{w}$ stosunku do wcześniejszych badań pilotażowych autora (STELMACH 2017a), w których były wzięte pod uwagę tylko uzdrowiska podkarpackie skupiające głównie uzdrowiska podgórskie. Do badań dołączono uzdrowiska nizinne $z$ województwa kujawsko-pomorskiego oraz nadmorskie $\mathrm{z}$ województwa pomorskiego. Tym samym zakres analiz zwiększył się o około $23 \%$ kuracjuszy stacjonarnych ogółem w Polsce oraz o 22\% kuracjuszy komercyjnych (głównie za sprawą objęcia badaniami Ciechocinka). Łącznie uwzględnione uzdro- wiska skupiały w 2015 r. 29\% kuracjuszy stacjonarnych ogółem $w$ Polsce oraz 26\% kuracjuszy stacjonarnych komercyjnych (według niepublikowanego zbioru danych udostępnionego przez Urząd Statystyczny w Krakowie).

W gminach uzdrowiskowych usługi uzdrowiskowe są dystrybuowane poprzez dwa wzajemnie się uzupełniające typy kanałów: rynkowy (komercyjny) i państwowy (socjalny). Proporcja ich udziału może być powiązana $z$ funkcją uzdrowiskową, będącą specyficzną funkcją turystyczną gmin uzdrowiskowych zorientowaną na działalność leczniczą odgrywająca szczególną rolę w ich gospodarce (SZROMEK 2012a, b 2015).

Dystrybucja polega na rozdzielaniu wytworzonych w gospodarce produktów, a dystrybucja usług uzdrowiskowych przebiega $\mathrm{z}$ wykorzystaniem dwóch wskazanych kanałów udostępniania tych usług osobom chcącym z nich korzystać, czyli kuracjuszom. Kanał dystrybucji usług uzdrowiskowych jest to sposób ich nabycia przez konsumenta od dostawcy (sanatorium 
lub szpitala uzdrowiskowego) (ROMANOVA, VETTINEV, DIMANCHE 2015). Kanały te różnią się źródłem finansowania i typem kuracjusza.

W ramach kanału socjalnego państwo dotuje usługi uzdrowiskowe w formie świadczeń rzeczowych dystrybuowanych pośrednio. Pośrednikami są najczęściej publiczni ubezpieczyciele: zdrowotny (w Polsce NFZ) i społeczny (ZUS i KRUS), a także inne podmioty (w szczególności PFRON). Adresatami tego kanału są tzw. kuracjusze niekomercyjni (niepełnopłatni), którymi są osoby objęte ubezpieczeniem zdrowotnym (chorobowym) lub społecznym, a także inni uprawnieni. Otrzymanie tego typu dofinansowania pośrednicy warunkują dostarczeniem stosownej dokumentacji lekarskiej.

Z kolei kanał rynkowy charakteryzuje się finansowaniem usług uzdrowiskowych ze środków własnych kuracjusza, tzw. komercyjnego (pełnopłatnego), i dystrybucją bezpośrednią, czyli zakupem usługi u samego dostawcy przez konsumenta.

Funkcja uzdrowiskowa jest częścią funkcji turystycznej, pojmowanej jako element struktury gospodarczej obszaru (ZMYŚLONY 2015), jedną z funkcji gospodarczych, określającą znaczenie turystyki w strukturze gospodarczej obszaru recepcji turystycznej (MAJEWSKA 2012, GOŁEMBSKI, MAJEWSKA 2015). Funkcja turystyczna oznacza zatem udział turystyki w gospodarce.

W porównaniu do lepiej zbadanych zagadnień funkcji turystycznej (DURYDIWKA 2012, MAJEWSKA 2012, SZROMEK 2012b, KOSMACZEWSKA 2013, GOŁEMBSKI, MAJEWSKA 2015, ZMYŚLONY 2015), funkcja uzdrowiskowa jawi się jak dotąd jako relatywnie skromny, ale rozwijany i interesujaccy przedmiot badań. Jest ona rozumiana jako specyficzna funkcja turystyczna gmin uzdrowiskowych, zorientowana na działalność leczniczą, odgrywająca szczególną rolę w ich gospodarce (SZROMEK 2012a, b 2015). Funkcja uzdrowiskowa jest uważana za jedną z zasadniczych funkcji turystycznych określonego terenu (SZROMEK 2015), która integruje zarówno działalność turystyczną z leczniczą, jak i cele społeczne $z$ ekonomicznymi. Jest to zatem aktywność społeczno-ekonomiczna prowadzona w uzdrowisku skierowana na obsługę kuracjuszy i funkcja, jaką uzdrowisko spełnia jednocześnie w systemie gospodarki narodowej oraz systemie ochrony zdrowia (SZROMEK 2012a).

Poszczególne obszary recepcji turystycznej różnią się od siebie pod względem poziomu, struktury i dynamiki rozwoju funkcji turystycznej. Gminy uzdrowiskowe, stanowiące szczególną formę obszarów recepcji turystycznej, zwykle ukierunkowują swoją działalność na lecznictwo uzdrowiskowe (jak to ma miejsce np. w Busku-Zdroju, Horyńcu-Zdroju, Iwoniczu-Zdroju, Rymanowie-Zdroju), niekiedy jednak przeważają w nich przyjazdy turystyczne, których ce- lem nie jest kuracja o charakterze stacjonarnym (SolecZdrój, Solina) (STELMACH 2017b, SZROMEK 2015).

W świetle powyższych rozważań, jak również biorąc pod uwagę operacjonalizację funkcji uzdrowiskowej zastosowaną we wcześniejszej pracy P. STELMACHA (2017a), funkcja uzdrowiskowa jest rozumiana tutaj jako udział gospodarki uzdrowiskowej w gospodarce turystycznej. Jak dotąd wypracowano przybliżony sposób pomiaru funkcji uzdrowiskowej, polegający na określaniu tego, jaką część noclegów udzielonych w destynacji turystycznej stanowią noclegi w zakładach uzdrowiskowych (sanatoriach i szpitalach uzdrowiskowych). Tak oszacowana funkcja uzdrowiskowa pozwala na uchwycenie podstawowej struktury funkcji turystycznej w gminach uzdrowiskowych.

W dalszych rozdziałach artykułu, po zaprezentowaniu metod i źródeł danych, celów i kombinacji technik badawczych, zostanie przeanalizowany oraz określony wzajemny wpływ funkcji uzdrowiskowej i struktury dystrybucji usług uzdrowiskowych na przykładzie wybranych gmin uzdrowiskowych.

\section{PRZEGLĄD LITERATURY}

Związek pomiędzy strukturą dystrybucji usług uzdrowiskowych a rozwojem funkcji uzdrowiskowej i turystycznej jak dotąd nie był przedmiotem naukowej eksploracji, z wyjątkiem jednego opracowania (STELMACHA 2017a), dotyczącego uzdrowisk podkarpackich. Skupiały one w 2015 r. 7\% liczby kuracjuszy stacjonarnych ogółem w Polsce oraz 4\% kuracjuszy komercyjnych (według niepublikowanego zbioru danych udostępnionego przez Urząd Statystyczny w Krakowie). Dotychczas przeprowadzone badania w bardzo niewielkim stopniu zestawiały zjawiska struktury dystrybucji usług uzdrowiskowych, funkcji uzdrowiskowej i funkcji turystycznej gmin, przeważnie analizując te zagadnienia rozłącznie.

Tematyka badań nad strukturą dystrybucji usług uzdrowiskowych skupiona była wokół charakterystyki samego zjawiska dwoistości i zróżnicowania kanałów dystrybucji tych usług (ROMANOVA, VETTINEV, DIMANCHE 2015, SZROMEK, ROMANIUK, HADZIK 2016, DRYGLAS, RÓŻYCKI 2016, 2017, DRYGLAS, SALAMAGA 2017, STELMACH 2017a, 2017a, b) oraz jego konsekwencji dla przedsiębiorstw uzdrowiskowych i gmin uzdrowiskowych (DERCO, PAVLISINOVA 2016, DRYGLAS, RÓŻYCKI 2016, 2017, DRYGLAS, SALAMAGA 2017, SZROMEK, ROMANIUK, HADZIK 2016, VRKLJAN, HENDIJA 2016). Z dotychczasowych badań w tych dwóch obszarach wynikają następujące wnioski (STELMACH 2017a):

1. Bieżąca nadmierna zależność uzdrowisk od pańsstwowego kanału dystrybucji usług uzdrowiskowych (dotycząca części krajów) jest ryzykow- 
na, gdyż nagłe prawne lub finansowe "szoki” regulacyjne mogą stanowić zagrożenie ekonomiczne dla przedsiębiorstw i gmin uzdrowiskowych $\mathrm{z}$ przesadnym udziałem tego kanału dystrybucji. Co więcej, kuracjusze niekomercyjni przynoszą mniej dochodu zarówno przedsiębiorstwom, jak i gminom uzdrowiskowym.

2. Kuracjusze komercyjni są kluczowymi klientami, ponieważ dostarczają większych zysków przedsiębiorstwom i destynacji w postaci większych wydatków oraz cenniejszych informacji zwrotnych. Dla części uzdrowisk ważnym rodzajem kuracjusza komercyjnego są kuracjusze zagraniczni. Zdolność do przyciągania kuracjusza komercyjnego jest wyzwaniem strategicznym uzdrowisk i może zaważyć na dalszym ich rozwoju.

Nie publikowano natomiast dotąd prac identyfikujących skutki jakie może rodzić struktura dystrybucji usług uzdrowiskowych dla rozwoju funkcji uzdrowiskowej lub turystycznej gmin. Nie analizowano również, czy poziom funkcji uzdrowiskowej lub turystycznej miejscowości może oddziaływać na strukturę dystrybucji jej usług uzdrowiskowych.

Analiza związku pomiędzy strukturą dystrybucji usług uzdrowiskowych a rozwojem funkcji uzdrowiskowej stanowi zatem nowy obszar badań. Jak dotąd ustalono (STELMACH 2017a), że dla 34 polskich gmin uzdrowiskowych traktowanych łącznie ${ }^{1}$, stanowiących 79\% gmin uzdrowiskowych w Polsce², występuje silna (współczynnik korelacji rang Spearmana równy - 0,9), istotna statystycznie, odwrotna korelacja między strukturą dystrybucji usług uzdrowiskowych (mierzoną jako udział liczby kuracjuszy komercyjnych w liczbie kuracjuszy ogółem) a funkcją uzdrowiskową (mierzoną jako jako udział liczby noclegów udzielonych w zakładach uzdrowiskowych w liczbie noclegów ogółem). W wymienionej pracy wysunięto jednak ograniczone przypuszczenia co do interpretacji tego wyniku, co skłania do pogłębienia analizy. W szczególności wskazane byłoby przeanalizowanie szeregów czasowych korelowanych wskaźników.

Z drugiej jednak strony, w przywoływanej pracy stwierdzono, że w przypadku gmin podkarpackich istnieją takie, jak np. Horyniec-Zdrój, dla których analizowana korelacja jest silna, istotna statystycznie i dodatnia, natomiast dla pozostałych gmin podkarpackich korelacje okazały się nieistotne statystycznie, ujemne oraz słabe lub przeciętne. Zatem ustalono, że w części gmin uzdrowiskowych rozpatrywany związek jest silniejszy, natomiast w części - wyraźnie słabszy. To zróżnicowanie również zasługuje na dalszą analizę i wyjaśnienie.

Nie prowadzono również weryfikacji w sytuacji, kiedy analizowany związek istnieje, czy ma on charakter zależności funkcyjnej. Hipotetyczną zmienną zależną byłaby w takich przypadkach funkcja uzdrowiskowa, podczas gdy struktura dystrybucji usług uzdrowiskowych byłaby traktowana jako zmienna niezależna. Można również rozpatrzyć zasadność analizowania zależności odwrotnej, tzn. struktury dystrybucji usług uzdrowiskowych od funkcji uzdrowiskowej. Oba punkty widzenia pogłębiają rozumienie specyfiki zarządzania destynacjami uzdrowiskowymi.

\section{METODA I ŹRÓDŁA DANYCH}

W tab 1. przedstawiono procedurę badań oraz uporządkowany zbiór technik badawczych i źródeł składających się na metodę rozwiązania sformułowanego na wstępie problemu.

Do realizacji postawionego celu i odpowiedzi na pytania badawcze wykorzystano techniki ilościowe. Analiza szeregów czasowych służy tutaj lepszemu zrozumieniu zmienności rozpatrywanych korelatów i zidentyfikowaniu ich własności, takich jak trendy, sezonowość czy momenty załamania strukturalnego. Analiza korelacji rang Spearmana wraz $\mathrm{z}$ testem $\mathrm{t}$-Studenta wykorzystywane są do identyfikacji statystycznie istotnych związków między zmiennymi o asymetrycznych rozkładach, przy niewielkiej liczbie dostępnych obserwacji. Analiza regresji prostej modeluje zależności między zmienną objaśnianą (którą hipotetycznie stanowi funkcja uzdrowiskowa) a zmienną objaśniającą (strukturą dystrybucji usług uzdrowiskowych). By jednak zweryfikować to przypuszczenie $\mathrm{w}$ badaniach $\mathrm{z}$ wykorzystaniem analizy regresji modelowano również rozpatrywany związek w odwrotnym porządku zmiennych, tzn. struktura dystrybucji usług uzdrowiskowych jako zmienna zależna a funkcja uzdrowiskowa jako zmienna niezależna.

Zakres analizowanej bazy danych obejmował 43 polskie gminy uzdrowiskowe, spośród których dla 34 gmin zidentyfikowano dostępne dane pozwalające wyznaczyć korelacje i zależności funkcyjne między rozpatrywanymi zmiennymi dla okresu 2005-2014. Szczegółowy zakres przestrzenny zrealizowanych badań, których wyniki przedstawiono poniżej, obejmował trzy gminy uzdrowiskowe województwa kujawsko-pomorskiego (Ciechocinek, Inowrocław i Brześć Kujawski), dwie gminy z pomorskiego (Ustka i Sopot) oraz cztery z podkarpackiego (Horyniec-Zdrój, Iwonicz-Zdrój, Rymanów i Solina).

Relatywnie mała liczba analizowanych obserwacji $(N=10,2005-2014)$ nie jest $\mathrm{w}$ tym wypadku uwarunkowana brakiem dbałości badacza o maksymalne wydłużenie szeregu czasowego danych, lecz okresem prowadzenia przez GUS statystyk dotyczących liczby kuracjuszy komercyjnych, a miało to miejsce dopiero 
Tab. 1. Etapy, źródła danych i techniki badań wykorzystane w procedurze ustalania korelacji zachodzących między strukturą dystrybucji usług uzdrowiskowych i funkcją uzdrowiskową

\begin{tabular}{|l|l|l|}
\hline \multicolumn{1}{|c|}{ Cel badań } & \multicolumn{1}{|c|}{ Źródła danych } & \multicolumn{1}{|c|}{ Techniki badawcze } \\
\hline $\begin{array}{l}\text { Identyfikacja szeregu } \\
\text { czasowego struktury } \\
\text { dystrybucji usług } \\
\text { uzdrowiskowych }\end{array}$ & $\begin{array}{l}\text { Panel danych wtórnych dotyczących 43 polskich gmin } \\
\text { uzdrowiskowych z lat 2005-2015, pochodzący z } \\
\text { niepublikowanego zbioru GUS pozyskanego z Urzędu } \\
\text { Statystycznego w Krakowie. }\end{array}$ & Analiza szeregów czasowych. \\
\hline $\begin{array}{l}\text { Identyfikacja szeregu } \\
\text { czasowego funkcji } \\
\text { uzdrowiskowej }\end{array}$ & $\begin{array}{l}\text { Panel danych wtórnych dotyczących 43 polskich gmin } \\
\text { uzdrowiskowych z lat 1995-2014 pochodzący z Banku } \\
\text { Danych Lokalnych GUS. }\end{array}$ & $\begin{array}{l}\text { 1. Analiza korelacji rang } \\
\text { Spearmana. }\end{array}$ \\
\hline $\begin{array}{l}\text { Określenie korelacji i zależ- } \\
\text { ności między strukturą } \\
\text { dystrybucji usług } \\
\text { uzdrowiskowych a funkcją } \\
\text { uzdrowiskową }\end{array}$ & $\begin{array}{l}\text { Panel danych wtórnych dotyczący 34 gmin } \\
\text { uzdrowiskowych z lat 2005-2014 pochodzący z } \\
\text { niepublikowanego zbioru GUS i Banku Danych Lokalnych } \\
\text { GUS. }\end{array}$ & $\begin{array}{l}\text { 2. Test t-Studenta istotności } \\
\text { statystycznej wskaźników } \\
\text { korelacji. } \\
\text { Analiza regresji. }\end{array}$ \\
\hline
\end{tabular}

Źródło: opracowanie własne.

od 2004 r. (a w przypadku udostępniania tych danych od 2005 r.) oraz wejściem w życie nowelizacji ustawy o statystyce publicznej z 2015 r., w wyniku której GUS zaprzestał udostępniania danych dotyczacych liczby udzielonych noclegów na poziomie gmin począwszy od 2015 r.

W celu pomiaru konstruktów teoretycznych wykorzystanych w badaniu dokonano operacjonalizacji pojecć struktury dystrybucji usług uzdrowiskowych oraz funkcji uzdrowiskowej. Podobnie jak w pracy P. STELMACHA (2017a), struktura dystrybucji usług uzdrowiskowych była mierzona poprzez:

$\begin{aligned} & \text { Wskaźnik struktury } \\ & \text { dystrybucji usług } \\ & \text { uzdrowiskowych }\end{aligned}$
liczba kuracjuszy stacjonarnych ogółem

- gdzie kuracjusze stacjonarni to pacjenci korzystający z opieki całodziennej lub całodobowej, tj. przebywający w sanatorium lub szpitalu uzdrowiskowym.

Z powodów przedstawionych w pracy P. STELMACHA (2017a) funkcję uzdrowiskową mierzono, stosując:

$$
\begin{gathered}
\begin{array}{l}
\text { Wskaźnik } \\
\text { funkcji uzdro- } \\
\text { wiskowej }
\end{array} \\
\text { liczba udzielonych noclegów ogółem }
\end{gathered}
$$

- gdzie zakład uzdrowiskowy to położony na terenie uzdrowiska zakład świadczący usługi w zakresie opieki zdrowotnej z wykorzystaniem naturalnych zasobów leczniczych uzdrowiska.

Głównym materiałem badawczym w niniejszej pracy były dane wtórne GUS pochodzące z dwóch zakresów statystyki publicznej: turystyki (formularz KT-1) i zdrowia (formularz ZD-2). Dane statystyki publicznej w zakresie turystyki są niepełne, gdyż obejmują jedynie rejestrowane obiekty noclegowe
(WŁODARCZYK, red. 2017, SZAFRAŃSKA, WŁODARCZYK, DZIEDZIC 2015), pomijając noclegi udzielone przez rodzinę, znajomych, w drugich domach, w kwaterach prywatnych itp., oraz noclegi udzielane w szarej strefie, tj. osobom niezgłoszonym $w$ oficjalnej sprawozdawczości przez obiekty nią objęte i noclegi udzielone przez podmioty prowadzące nielegalną działalność gospodarczą.

Z drugiej jednak strony należy zauważyć, że jakkolwiek badania pierwotne ruchu turystycznego dają dokładniejsze wyniki niż badania wtórne, tym niemniej w sytuacji braku badań pierwotnych - a tak jest $\mathrm{w}$ tym przypadku - ich podjęcie należy poprzedzić analizą danych wtórnych. Dane ze statystyki publicznej stanowią bowiem podstawę oceny zjawisk turystycznych i punkt odniesienia do projektowania i realizacji badań pierwotnych (DZIEDZIC, red. 2010), służąc do ustalenia operatu losowania (BORKOWSKI $i$ in. 2017) i struktury próby badawczej (WŁODARCZYK, red. 2017), stanowiąc zarazem podstawę szacunków statystycznych liczby turystów. Ponadto dane GUS mają walor ciągłości i względnej jednolitości metodycznej, jakiego nie posiada większa część badań pierwotnych, co powoduje ich bezużyteczność w identyfikacji zależności stałych w czasie. W tym stanie rzeczy należy uznać za uzasadnione korzystanie $\mathrm{z}$ danych wtórnych $\mathrm{w}$ niniejszych badaniach.

\section{WYNIKI}

Zgodnie z kolejnością procedury badawczej zidentyfikowane szeregi czasowe struktury dystrybucji usług uzdrowiskowych przedstawiono na rys. 1 . 


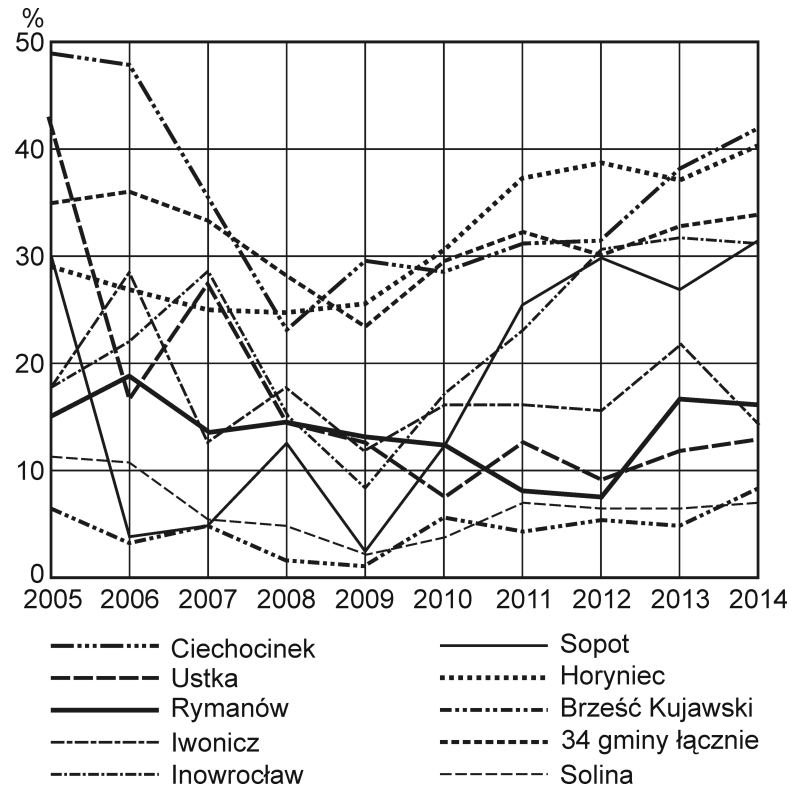

Rys. 1. Dynamika struktury dystrybucji usług uzdrowiskowych w gminach kujawsko-pomorskich, pomorskich i podkarpackich w latach 2005-2014

Źródło: opracowanie własne na podstawie niepublikowanego zbioru danych GUS pozyskanego z US w Krakowie

Na rys. 1. zauważalny jest pewien wspólny wzorzec rozwoju udziału liczby kuracjuszy pełnopłatnych w liczbie kuracjuszy ogółem analizowanych gmin. Ma on charakter procykliczny, tzn. zgodny z cyklami gospodarczymi, co jest widoczne zwłaszcza w odniesieniu do serii danych odnoszących się do wcześniej wspomnianych 34 gmin uzdrowiskowych analizowanych łącznie. Ponadprzeciętny udział kuracjuszy komercyjnych wystąpił $\mathrm{w}$ omawianym okresie zwłaszcza w gminach Horyniec-Zdrój i Ciechocinek. W roku 2014 strukturę dystrybucji usług uzdrowiskowych zbliżoną do średniej ogólnopolskiej posiadały też Inowrocław i Sopot. Natomiast bardzo niski udział kuracjuszy komercyjnych występuje w uzdrowisku Wieniec-Zdrój i Polańczyk-Zdrój.

$Z$ kolei zidentyfikowane szeregi czasowe funkcji uzdrowiskowej przedstawiono na rys. 2, na którym zauważalna jest odmienność struktury udzielonych noclegów gmin uzdrowiskowych kujawsko-pomorskich i podkarpackich (z wyjątkiem Soliny) w stosunku do pomorskich. Kujawsko-pomorskie i większość podkarpackich gmin uzdrowiskowych wyróżnia się skupieniem udzielonych noclegów w zakładach uzdrowiskowych, podczas gdy w uzdrowiskach pomorskich i w gminie Solina przeważają noclegi poza zakładami uzdrowiskowymi. Przebieg zmienności wskaźnika funkcji uzdrowiskowej dla 34 gmin łącznie sugeruje antycykliczność, tzn. ujemne skorelowanie z okresami ożywienia wzrostu gospodarczego. Jest on także odwróceniem zmienności wskaźnika struktury dystrybucji usług uzdrowiskowych dla 34 gmin wi- docznym na rys. 1, co jest częściowym wyjaśnieniem silnego ujemnego związku korelacyjnego zidentyfikowanego we wcześniejszej pracy P. STELMACHA (2017a), przywołanego także $\mathrm{w}$ tab. 2, przedstawiającej oszacowanie korelacji wskaźników zilustrowanych na rys. 1 i 2.

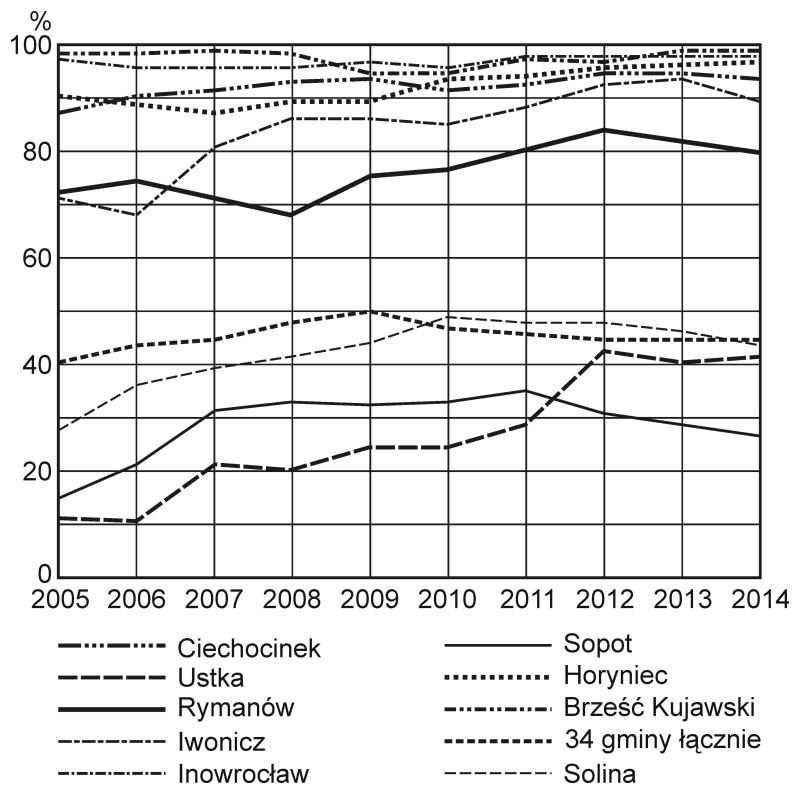

Rys. 2. Dynamika funkcji uzdrowiskowej w gminach kujawsko-pomorskich, pomorskich i podkarpackich w latach 2005-2014 Źródło: opracowanie własne na podstawie Banku Danych Lokalnych GUS

Dla gminy Ustka oszacowano silny $i$ istotny statystycznie ujemny związek między strukturą dystrybucji usług uzdrowiskowych a funkcją uzdrowiskową. Z kolei dla gminy Horyniec-Zdrój analizowana korelacja jest silna, istotna statystycznie i dodatnia, natomiast dla Inowrocławia oszacowano silną i niewiele mniejszą od progu istotności statystycznej dodatnią korelację. Dla pozostałych gmin korelacje były nieistotne statystycznie i przeciętne (Sopot i Solina) bądź słabe (Brześć Kujawski, Ciechocinek, Iwonicz-Zdrój i Rymanów). Przeważała korelacja ujemna (w 6 gminach) nad dodatnią (w 3 gminach). Należy przy tym zauważyć, że $\mathrm{w}$ przypadku niewielkiej liczby obserwacji - jak w omawianym badaniu - trudniej jest potwierdzić istotność statystyczną współczynnika korelacji i aby to się udało, trzeba zidentyfikować związek o dużej sile.

Słabe i przeciętne, a zarazem nieistotne statystycznie współczynniki korelacji rang Spearmana zazwyczaj, choć nie zawsze, sugerują możliwość wystąpienia zależności funkcyjnych o podobnej sile i nieistotności statystycznej. Zdecydowano się jednak na sprawdzenie tego, czy tak jest i w tym przypadku modelując rozpatrywane zmienne $z$ wykorzystaniem techniki 
Tab. 2. Współczynniki korelacji rang Spearmana między strukturą dystrybucji usług uzdrowiskowych a funkcją uzdrowiskową badanych gmin w latach 2005-2014

\begin{tabular}{|c|c|c|c|c|c|}
\hline Brześć Kujawski & Ciechocinek & Inowrocław & Sopot & Ustka & $\begin{array}{c}\text { Wartość krytyczna współczynnika } \\
\text { korelacji dla } N=10 \text { i } p=0,05 \\
\text { (dwustronny obszar krytyczny) }\end{array}$ \\
\hline 0,30 & $-0,28$ & $\mathbf{0 , 6 1}$ & $-0,44$ & $\mathbf{- 0 , 7 5}$ & 0,65 \\
\hline Horyniec-Zdrój & Iwonicz-Zdrój & Rymanów & Solina & 34 gminy & $\mathbf{- 0 , 9 0}$ \\
\hline $\mathbf{0 , 8 8}$ & $-0,21$ & $-0,28$ & $-0,48$ & 0 \\
\hline
\end{tabular}

Źródło: opracowanie własne na podstawie Banku Danych Lokalnych GUS i niepublikowanego zbioru danych GUS pozyskanego z US w Krakowie.

prostej analizy regresji liniowej klasyczną metodą najmniejszych kwadratów (z wykorzystaniem programu ekonometrycznego Gretl). By określić poprawność specyfikacji modelu, w szczególności wybór zmiennej zależnej, porównywano modele $z$ estymowanymi tą samą techniką - modelami zależności odwrotnej, tzn. model pierwszy dla zmiennej zależnej „,funkcja uzdrowiskowa” i zmiennej niezależnej „struktura dystrybucji usług uzdrowiskowych" porównywano każdorazowo z modelem drugim o zmiennej zależnej „struktura dystrybucji usług uzdrowiskowych" i zmiennej niezależnej „funkcja uzdrowiskowa”. Dla większości oszacowań model pierwszy charakteryzował się lepszym, tj. o niższych wartościach, kryterium informacyjnym Akaike'a. Zestaw tych modeli przedstawiono w tab. 3.

Tab. 3. Estymacja klasyczną metodą najmniejszych kwadratów dla zmiennej zależnej "funkcja uzdrowiskowa” i zmiennej niezależnej „struktura dystrybucji usług uzdrowiskowych”

\begin{tabular}{|c|c|c|c|c|c|}
\hline Gmina & \multicolumn{2}{|c|}{ Współczynnik } & $\begin{array}{c}\text { Wartość } \\
p\end{array}$ & $R 2$ & $\begin{array}{l}\text { Kryterium } \\
\text { informacyjne }\end{array}$ \\
\hline \multirow[b]{2}{*}{$\begin{array}{l}34 \text { gminy } \\
\text { łącznie }\end{array}$} & przecięcie & 0,64 & $<0,0001$ & \multirow[b]{2}{*}{0,81} & \multirow[b]{2}{*}{-59} \\
\hline & $\begin{array}{c}\text { struktura } \\
\text { dystrybucji }\end{array}$ & $-0,61$ & 0,0004 & & \\
\hline \multirow{2}{*}{$\begin{array}{l}\text { Horyniec- } \\
\text {-Zdrój }\end{array}$} & przecięcie & 0,74 & $<0,0001$ & \multirow[b]{2}{*}{0,89} & \multirow[b]{2}{*}{-57} \\
\hline & $\begin{array}{c}\text { struktura } \\
\text { dystrybucji }\end{array}$ & 0,57 & $<0,0001$ & & \\
\hline \multirow{2}{*}{$\begin{array}{l}\text { Ciecho- } \\
\text { cinek }\end{array}$} & przecięcie & 0,97 & $<0,0001$ & \multirow[b]{2}{*}{0,32} & \multirow[b]{2}{*}{-48} \\
\hline & $\begin{array}{c}\text { struktura } \\
\text { dystrybucji }\end{array}$ & $-0,15$ & 0,091 & & \\
\hline \multirow{2}{*}{$\begin{array}{l}\text { Inowro- } \\
\text { cław }\end{array}$} & przecięcie & 0,96 & $<0,0001$ & \multirow[b]{2}{*}{0,31} & \multirow[b]{2}{*}{-70} \\
\hline & $\begin{array}{c}\text { struktura } \\
\text { dystrybucji }\end{array}$ & 0,05 & 0,0932 & & \\
\hline \multirow[b]{2}{*}{$\begin{array}{l}\text { Brzesść } \\
\text { Kujawski }\end{array}$} & przecięcie & 0,97 & $<0,0001$ & \multirow[b]{2}{*}{0,14} & \multirow[b]{2}{*}{-56} \\
\hline & $\begin{array}{c}\text { struktura } \\
\text { dystrybucji }\end{array}$ & 0,24 & 0,28 & & \\
\hline \multirow[b]{2}{*}{ Sopot } & przecięcie & 0,31 & $<0,0001$ & \multirow[b]{2}{*}{0,07} & \multirow[b]{2}{*}{-25} \\
\hline & $\begin{array}{c}\text { struktura } \\
\text { dystrybucji }\end{array}$ & $-0,14$ & 0,45 & & \\
\hline
\end{tabular}

Źródło: opracowanie własne.

W mniejszej części przypadków model drugi charakteryzował się lepszym kryterium informacyjnym Akaike'a; parametry tych modeli opisano w tab. 4 .
Tab. 4. Estymacja klasyczną metodą najmniejszych kwadratów dla zmiennej zależnej „struktura dystrybucji usług uzdrowiskowych" i zmiennej niezależnej „funkcja uzdrowiskowa”

\begin{tabular}{|c|c|c|c|c|c|}
\hline Gmina & \multicolumn{2}{|c|}{ Współczynnik } & \multirow{2}{*}{\begin{tabular}{|c} 
Wartość \\
$p$
\end{tabular}} & \multirow{3}{*}{$\begin{array}{c}R 2 \\
\mathbf{0 , 4 9}\end{array}$} & \multirow{3}{*}{$\begin{array}{c}\text { Kryterium } \\
\text { informa- } \\
\text { cyjne } \\
\text { Akaike'a } \\
-46\end{array}$} \\
\hline \multirow[b]{2}{*}{ Solina } & przecięcie & 0,52 & & & \\
\hline & $\begin{array}{c}\text { funkcja } \\
\text { uzdrowiskowa }\end{array}$ & $-1,61$ & 0,0244 & & \\
\hline \multirow[b]{2}{*}{ Ustka } & przecięcie & 0,37 & 0,0003 & \multirow[b]{2}{*}{0,36} & \multirow[b]{2}{*}{-18} \\
\hline & $\begin{array}{c}\text { funkcja } \\
\text { uzdrowiskowa }\end{array}$ & $-0,65$ & 0,065 & & \\
\hline \multirow{2}{*}{$\begin{array}{l}\text { Iwonicz- } \\
\text {-Zdrój }\end{array}$} & przecięcie & 0,98 & $<0,0001$ & \multirow[b]{2}{*}{0,21} & \multirow[b]{2}{*}{-32} \\
\hline & $\begin{array}{c}\text { funkcja } \\
\text { uzdrowiskowa }\end{array}$ & $-0,81$ & 0,19 & & \\
\hline \multirow[b]{2}{*}{ Rymanów } & przecięcie & 0,84 & $<0,0001$ & \multirow[b]{2}{*}{0,16} & \multirow[b]{2}{*}{-37} \\
\hline & $\begin{array}{c}\text { funkcja } \\
\text { uzdrowiskowa }\end{array}$ & $-0,57$ & 0,2472 & & \\
\hline
\end{tabular}

Źródło: opracowanie własne.

Weryfikacji istotności statystycznej zmiennej objaśniającej, przy poziomie $\alpha=0,1$, dokonano na podstawie hipotez:

H0: zmienna niezależna istotnie wpływa na zmienną objaśnianą,

H1: zmienna niezależna nie wpływa istotnie na zmienną objaśnianą.

Jak pokazują badania, głównie tab. 3, uzyskano w szczególności bardzo dobrze dopasowaną i istotną statystycznie zależność funkcji uzdrowiskowej od struktury dystrybucji usług uzdrowiskowych dla 34 gmin analizowanych łącznie, Horyńca-Zdroju i Soliny oraz umiarkowanie dopasowane $\mathrm{i}$ istotne statystycznie zależności dla Ustki (tab. 4) i Inowrocławia, a także - co zaskakuje w świetle stwierdzonego wcześniej słabego związku korelacyjnego (tab. 2) - dla Ciechocinka. Dla Iwonicza-Zdroju, Rymanowa, Brześcia Kujawskiego i Sopotu zależności okazały się natomiast niedopasowane i nieistotne statystycznie. Zatem ustalono, że rozpatrywany związek, mający charakter zależności, jest silniejszy w części gmin uzdrowiskowych, natomiast w części - wyraźnie słabszy. Wyjaśnienie tego zróżnicowania wymaga jednak dalszych badań. 
Na podstawie analizy rys. 1 i 2 można natomiast wysnuć przypuszczenie, że jedną z przyczyn ujemnej zależności funkcji uzdrowiskowej od struktury dystrybucji usług uzdrowiskowych dla 34 gmin analizowanych łącznie jest antycykliczność funkcji uzdrowiskowej oraz symetrycznie przebiegająca procykliczność struktury dystrybucji usług uzdrowiskowych.

Z kolei weryfikując wcześniejsze przypuszczenie (STELMACH 2017a) trzeba zauważyć, że dla większej części uzdrowisk, dla których analizowane zależności są statystycznie istotne, funkcja uzdrowiskowa jest ujemnie skorelowana ze strukturą dystrybucji usług uzdrowiskowych, przy czym w dwóch z nich (Ciechocinek i Solina) funkcja uzdrowiskowa jest ekstensywnie rozwijana, obniżając udział rynkowego kanału dystrybucji i pogłębiając tym samym zależność od państwowego kanału dystrybucji. W Ciechocinku funkcja uzdrowiskowa uwarunkowana jest strukturą dystrybucji usług uzdrowiskowych, natomiast w Solinie i Ustce funkcja uzdrowiskowa ma wpływ na strukturę dystrybucji usług uzdrowiskowych. W drugiej grupie uzdrowisk (Horyniec-Zdrój i Inowrocław) występujące zwiększenie roli funkcji uzdrowiskowej wynika $\mathrm{z}$ rosnącego udziału komercyjnego kanału dystrybucji.

Dotychczasowa analiza ujawnia zatem istnienie trzech odmiennych wzorców rozwojowych różnych uzdrowisk, w których zachodzi związek między funkcją uzdrowiskową a strukturą dystrybucji usług uzdrowiskowych.

\section{WNIOSKI}

Zrealizowane badania pozwoliły na odpowiedź na postawione pytanie badawcze dla dziewięciu analizowanych gmin uzdrowiskowych $\mathrm{z}$ województw kujawsko-pomorskiego, pomorskiego i podkarpackiego:

1. W trzech gminach struktura dystrybucji usług uzdrowiskowych ma istotny wpływ na funkcję uzdrowiskową.

2. W dwóch gminach funkcja uzdrowiskowa ma istotny wpływ na strukturę dystrybucji usług uzdrowiskowych.

3. W czterech gminach funkcja uzdrowiskowa i struktura dystrybucji usług uzdrowiskowych nie wpływają na siebie wzajemnie.

Ponadto ustalono, że przypuszczalnym wyjaśnieniem ujemnej zależności funkcji uzdrowiskowej od struktury dystrybucji usług uzdrowiskowych dla 34 polskich gmin analizowanych łącznie jest antycykliczność funkcji uzdrowiskowej oraz symetryczna procykliczność struktury dystrybucji usług uzdrowiskowych.

Zidentyfikowano istnienie dwóch odmiennych wzorców rozwojowych uzdrowisk, w których wystę- puje związek między funkcją uzdrowiskową a strukturą dystrybucji usług uzdrowiskowych:

1. Ekstensywny wzrost funkcji uzdrowiskowej oparty na wzroście udziału kuracjuszy niekomercyjnych.

2. Intensywny wzrost funkcji uzdrowiskowej zależny od rosnącego udziału komercyjnego kanału dystrybucji.

Te odmienne wzorce rozwojowe mogą mieć wpływ na bilans korzyści z obsługi kuracjuszy i turystów przedsiębiorstw oraz gmin uzdrowiskowych działających na poszczególnych obszarach. Staje się zatem jasne, że obrany kierunek badań jest ważny z punktu widzenia gmin uzdrowiskowych, których władze gospodarują i zarządzają funkcją uzdrowiskową jako funkcją turystyczną o szczególnym znaczeniu. Realizują to we współpracy $\mathrm{z}$ przedsiębiorstwami lecznictwa uzdrowiskowego, stosującymi określone struktury dystrybucji usług uzdrowiskowych, oraz innymi przedsiębiorstwami zaspokajającymi potrzeby odwiedzających uzdrowiska.

Biorąc pod uwagę fakt, że przedsiębiorcy obsługujący odwiedzających destynacje uzdrowiskowe są często zainteresowani maksymalizacją zysków na drodze maksymalizacji przychodów, rodzi się również pytanie, jaka jest zależność przychodów uzdrowisk od wyodrębnionych profili rozwojowych uzdrowisk. Wydaje się również warte rozważenia to, czy sukces ekonomiczny destynacji uzdrowiskowej uwarunkowany jest udziałem kuracjuszy niekomercyjnych $\mathrm{w}$ liczbie turystów ogółem. Innymi słowy, chodzi o empiryczną ocenę wpływu struktury odwiedzających uzdrowiska na korzyści gospodarcze destynacji, zwłaszcza że ta struktura odwiedzających, której częścią jest struktura dystrybucji usług uzdrowiskowych, różni się w poszczególnych gminach uzdrowiskowych, ujawniając różny stopień i kierunek powiązań między rozpatrywanymi wskaźnikami struktury. Obrany nurt badań może stać się w przyszłości podstawą wskazania kierunków rozwoju społeczno-ekonomicznego gmin uzdrowiskowych.

\section{PRZYPISY}

1 Są to następujące gminy uzdrowiskowe: Augustów (gmina miejska), Brześć Kujawski (uzdrowisko Wieniec-Zdrój), Busko-Zdrój, Ciechocinek, Darłowo (Dąbki), Duszniki-Zdrój, Goczałkowice-Zdrój, Gołdap, Horyniec-Zdrój, Inowrocław, Iwonicz-Zdrój, Jelenia Góra (Cieplice Śląskie-Zdrój), Kołobrzeg, Kraków (Swoszowice), Krynica-Zdrój, Kudowa-Zdrój, Lądek-Zdrój, Muszyna, Nałęczów, Niemcza (Przerzeczyn-Zdrój), Polanica-Zdrój, Połczyn-Zdrój, Rabka-Zdrój, Rymanów, Solina (Polańczyk-Zdrój), Solec-Zdrój, Sopot, Szczawnica, Szczawno-Zdrój, Świeradów-Zdrój, Świnoujście, Ustka (gmina miejska), Ustron, Uście Gorlickie (Wysowa).

2 Dla dziewięciu gmin braki $\mathrm{w}$ danych nie pozwoliły na oszacowanie współczynników korelacji: Bystrzyca Kłodzka 
(Długopole-Zdrój), Jedlina-Zdrój, Kamień Pomorski, Konstancin-Jeziorna, Krasnobród, Sękowa (Wapienne), Supraśl i Uniejów.

\section{BIBLIOGRAFIA}

BORKOWSKI K., GRABIŃSKI T., SEWERYN R., MAZANEK L., GRABIŃSKA E., 2017, Ruch turystyczny w Krakowie w 2016 roku, Małopolska Organizacja Turystyczna, Kraków.

DERCO J., PAVLISINOVA D., 2016, Financial position of medical spas - the case of Slovakia, „Tourism Economics”, 23(4), s. 867-873, doi: $10.5367 /$ te.2016.0553.

DRYGLAS D., RÓŻYCKI P., 2016, European spa resorts in the perception of non-commercial and commercial patients and tourists: the case study of Poland, "E-review of Tourism Research” (eRTR), 13(1/2), s. 382-400.

DryGlas D., SAlamagA M., 2017, Applying destination attribute segmentation to health tourists: A case study of Polish spa resorts, "Journal of Travel and Tourism Marketing", 34(4), s. 503 -514, doi: 10.1080/10548408.2016.1193102.

DRYGLAS D., RÓŻYCKI P., 2017, Profile of tourists visiting European spa resorts: a case study of Poland, "Journal of Policy Research in Tourism, Leisure and Events", s. 1-20, doi: 10.1080/1940 7963.2017.1297311.

DURYDIWKA M., 2012, Czynniki rozwoju i zróżnicowanie funkcji turystycznej na obszarach wiejskich w Polsce, Wyd. Wydziału Geografii i Studiów Regionalnych Uniwersytetu Warszawskiego, Warszawa.

DZIEDZIC E. (red.), 2010, Regionalne badania konsumentów ustug turystycznych, Polska Organizacja Turystyczna, Warszawa.

GOŁEMBSKI G., MAJEWSKA J., 2015, Ocena oddziatywania samorządu na rozwój funkcji turystycznej dużego miasta, [w:] G. Gołembski i in. (red.), Turystyka w badaniach ekonomicznych, Wyd. Naukowe PWN, Warszawa, s. 41-60.

KOSMACZEWSKA J., 2013, Turystyka jako czynnik rozwoju obszarów wiejskich, Bogucki Wyd. Naukowe, Poznań.

MAJEWSKA J., 2012, Rola samorzadu terytorialnego w ksztattowaniu funkcji turystycznej gminy, Wyd. Uniwersytetu Ekonomicznego w Poznaniu, Poznań.
Romanova G.M., VetTinev A., DimAnche F., 2015, Health and wellness tourism, [w:] F. Dimanche, L. Andrades (red.), Tourism in Russia: A management handbook, "Emerald", s. 231-287.

STELMACH P., 2017a, Struktura dystrybucji ustug uzdrowiskowych a funkcja uzdrowiskowa gmin. Koncepcja i wstępne wyniki badań, „Prace Naukowe Uniwersytetu Ekonomicznego we Wrocławiu", w druku.

STELMACH P., 2017b, Trendy dystrybucji ustug uzdrowiskowych w gminach województwa podkarpackiego, [w:] B. Gierczak-Korzeniowska (red.), Turystyka a rozwój regionalny - szanse, wyzwania, perspektywy, Wyd. Uniwersytetu Rzeszowskiego, Rzeszów, w druku.

SZAFRAŃSKA E., WŁODARCZYK B., DZIEDZIC E., 2015, Pomiar wielkości ruchu turystycznego w regionie, [w:] E. Dziedzic (red.), Badania konsumentów ustug turystycznych w regionach, Polska Ogranizacja Turystyczna, Warszawa.

SZROMEK A.R., 2012a, Funkcja uzdrowiskowa i jej znaczenie w gospodarce gmin uzdrowiskowych, [w:] A. Szromek (red.), Uzdrowiska $i$ ich funkcja turystyczno-lecznicza, Proksenia, Kraków, s. 35-57.

SZROMEK A.R., 2012b, Wskaźniki funkcji turystycznej. Koncepcja wskaźnika funkcji turystycznej i uzdrowiskowej, Wyd. Politechniki Śląskiej, Gliwice.

SZROMEK A.R., 2015, Realizacja funkcji uzdrowiskowej w gminach uzdrowiskowych województwa świętokrzyskiego, Zeszyty Naukowe Politechniki Śląskiej, ser. „Organizacja i Zarządzanie”, 82, 1940, s. 289-299.

SZROMEK A.R., ROMANIUK P., HADZIK A., 2016, The privatization of spa companies in Poland - An evaluation of policy assumptions and implementation, "Health Policy”, 120, s. 362-368.

VRKLJAN S., HENDIJA Z., 2016, Business performance of health tourism service providers in the Republic of Croatia, "Acta Clinica Croatica", 55(1), s. 79-85.

WŁODARCZYK B. (red.), 2017, Cel i zakres opracowania oraz materiały źródtowe i metody badań, [w:] Włodarczyk B. (red.), Ruch turystyczny w Łodzi i województwie tódzkim, Instytut Geografii Miast i Turyzmu, Uniwersytet Łódzki, Łódź.

ZMYŚLONY P., 2015, Funkcja turystyczna w procesie internacjonalizacji miast, Proksenia, Kraków.

Artykuł wpłyną:

18 czerwca $2017 \mathrm{r}$

Zaakceptowano do druku:

27 lipca 2017 r. 